\title{
TRANSHIATAL ESOPHAGECTOMY IS NOT ASSOCIATED WITH POOR QUALITY LYMPHADENECTOMY
}

\author{
Esofagectomia trans-hiatal não está associada com linfadenectomia de baixa qualidade \\ Flávio Roberto TAKEDA ${ }^{1}$, Francisco TUSTUMI', Bruna de Camargo NIGRO', \\ Rubens Antonio Aissar SALLUM ${ }^{1}$, Ulysses RIBEIRO-JUNIOR ${ }^{1}$, Ivan CECCONELLO ${ }^{1}$
}

How to cite this article: Takeda FR, Tustumi F, Nigro BC, Sallum RAA, Ribeiro-Junior U, Cecconello I. Transhiatal esophagectomy is not associated with poor quality lymphadenectomy. ABCD Arq Bras Cir Dig. 2019;32(4):e1475. DOI: /10.1590/0102-672020190001e1475

From the ${ }^{1}$ Departamento de Gastroenterologia, Universidade de São Paulo, São Paulo, SP, Brasil ('Gastroenterology Department, University of São Paulo, São Paulo, SP, Brazil)

HEADINGS - Esophageal neoplasms. Neoadjuvant therapy. Esophagectomy.
ABSTRACT - Background: Esophageal cancer neoadjuvant therapy followed by surgery increases the likelihood of treatment success. Aim: To evaluate variables that can influence the number of retrieved lymph nodes, the number of retrieved metastatic lymph nodes and lymphnodal recurrence in esophagectomy after neoadjuvant chemoradiotherapy. Methods: Patients of a single institute were evaluated after completion of trimodal therapy. Univariate and multivariate analyses were performed to evaluate variables that can influence in the number of retrieved lymph nodes and retrieved metastatic lymph nodes. Results: One hundred and fortynine patients were included. Thoracoscopy access was considered an independent factor for the number of lymph nodes retrieved, but was neither related to the number of positive lymph nodes retrieved nor to lymphnodal recurrence. Pathological complete response on the primary tumor and male were independent variables associated with the number of positive lymph node retrieved. Pathological complete response on the primary tumor site did not statistically influence the likelihood of a lower number of lymph nodes retrieved. Conclusion: Patients submitted to esophagectomy after neoadjuvant chemoradiotherapy, thoracoscopic access is more accurate for pathological staging, even in a complete pathological response. With a proper patient selection, transhiatal surgery may preserve the quality of lymphadenectomy of the positive lymph nodes.

\section{Correspondence:}

Francisco Tustumi

E-mail: franciscotustumi@gmail.com

Financial source: none

Conflict of interest: none

Received for publication: 20/08/2019

Accepted for publication: 01/10/2019

DESCRITORES - Terapia neoadjuvante Esofagectomia. Neoplasias esofágicas
RESUMO - Racional: No câncer esofágico a terapia neoadjuvante seguida de procedimento cirúrgico aumenta a probabilidade de sucesso do tratamento. Objetivo: Avaliar variáveis que podem influenciar o número de linfonodos recuperados, o número de linfonodos metastáticos recuperados e a recorrência linfonodal na esofagectomia após quimiorradioterapia neoadjuvante. Métodos: Os pacientes incluídos foram aqueles que terminaram terapia trimodal. Análises univariadas e multivariadas foram realizadas para avaliar as variáveis que pudessem influenciar no número de linfonodos recuperados e nos metastáticos recuperados. Resultados: Cento e quarenta e nove pacientes foram incluídos. O acesso por toracoscopia foi considerado fator independente para o número de linfonodos recuperados, mas não teve relação com o número de linfonodos positivos recuperados, nem com recorrência linfonodal. Resposta patológica completa no tumor primário e homens foram variáveis independentes associadas ao número de linfonodos positivos recuperados. A resposta patológica completa do tumor primário não acarretou em número menor de linfonodos recuperados. Conclusão: Em pacientes submetidos à esofagectomia após quimiorradioterapia neoadjuvante o acesso toracoscópico é mais preciso para estadiamento patológico, mesmo em resposta patológica completa. Com seleção adequada a esofagectomia trans-hiatal pode preservar a qualidade da linfadenectomia dos linfonodos positivos.

\section{INTRODUCTION}

Eophageal cancer is a growing health issue expected to increase in

- incidence over the next years due to the upsurge of gastroesophageal reflux disease and obesity $y^{4,15}$. It is still a challenging disease with a poor prognosis despite the advances in chemoradiotherapy ${ }^{2}$ and all the progress made in the last years in minimally invasive surgery and postoperative management ${ }^{19}$.

The prognosis of this aggressive neoplasm depends mainly on the local invasion extension, hematogenous metastasis, and lymphatic spread ${ }^{20}$. Surgical resection is the primary treatment for localized esophageal carcinoma, and a properly lymphadenectomy is crucial for long-term survival ${ }^{12}$. Both the number of lymph nodes retrieved during esophagectomy and the metastatic lymph correlated with survival rates ${ }^{1,21}$. Also, lymph node status is crucial for neoplasm staging and, thus, for establishing prognosis and treatment strategies ${ }^{7,11,23}$. 
On the other hand, good quality lymphadenectomy may be challenging after chemoradiation, once it leads to the formation of fibrosis inside the radiation field ${ }^{8,9,18}$. Also, systemic neoadjuvant chemotherapy may modify the number and the distribution of mediastinal lymph nodes and also affect metastatic lymph nodes ${ }^{9}$. At the same time, neoadjuvant chemoradiation therapy is the standard treatment for most localized esophageal neoplasms, once it can improve long-term survival by controlling of locoregional disease, tumor downstaging before surgery, and targeting micrometastases, decreasing the risk of distant metastasis ${ }^{14,22}$

This retrospective cohort study aims to evaluate the variables that can influence the quality of lymphadenectomy in esophagectomy after neoadjuvant chemoradiotherapy using platinum- and taxane-based regimen. For lymphadenectomy quality assessment, this study evaluated the number of lymph nodes retrieved ( $\mathrm{LNr}$ ), the number of positive lymph nodes retrieved (PLNr), and lymphnodal recurrence rate.

\section{METHODS}

This study was approved by institutional ethics committee with number 3.315 .331

\section{Study design}

This is a retrospective cohort in which patients of a single institute with completion of neoadjuvant chemoradiotherapy using platinum- and taxane-based regimens, followed by curative intent esophagectomy, were selected. Radiation dose ranged from 41.4 to $50.4 \mathrm{cGy}$. A transthoracic approach with two-field lymph-node dissection was performed for tumors extending proximally to the tracheal bifurcation. A transhiatal resection was preferred for tumors involving the esophagogastric junction. Patients were recruited from 2009 to 2019, and were staged with endoscopy, CT-scan, and PET-Scan before neoadjuvant therapy and classified according to the $8^{\text {th }}$ edition of UICC staging ${ }^{16}$. Patients were followed with clinical exams, endoscopies, and CTscans. The endpoints evaluated were the number of lymph nodes retrieved ( $\mathrm{LNr}$ ), the number of positive lymph nodes retrieved (PLNr), and lymphnodal recurrence rate.

\section{Statistical analysis}

Chi-square test or likelihood-ratio test were used for each outcome for absolute and relative variables. Kruskal-Wallis and ANOVA tests were used to assess for significant differences on a continuous dependent variable by a categorical independent variable. Multivariate Cox proportional hazard analysis was performed to determine independent risk factors for the outcomes. Only variables that were significant on univariate analysis were included as covariates in the multivariable analyses. Data were assessed with IBM-SPSS software version 20.0, and a significance level of 0.05 was adopted.

\section{RESULTS}

Were enrolled 149 consecutive patients between 2009 and 2019 that have undergone neoadjuvant chemoradiotherapy using platinum- and taxane-based regimen followed by curative intent esophagectomy. The mean age was 61.5 years $(S D \pm 8.1)$, with male predominance $(76 \%)$. There were 101 squamous cell carcinoma (SCC) and 48 esophageal adenocarcinoma patients. The mean follow-up was 31.3 months $(S D \pm 22)$.

The median number of lymph nodes retrieved (LNr) was 19. Patients were grouped as up to 19 and more than 19 LN for univariate analysis (Table 1). Surgical access $(p<0.001)$ and age $(p=0.003)$ influenced the number of LNr in esophagectomy. Pathological complete response ( $P C R)$ on the primary tumor site did not statistically influence the likelihood of a lower number of LNr (OR $0.81 ; 95 \% \mathrm{Cl}$ : $0.41-1.56 ; p=0.536)$. When analyzing each surgical access separately (transhiatal or thoracoscopy), pCR was still not statistically associated with the number of LNr (Table 2). In multiple regression analysis, only thoracoscopy access was considered an independent factor (OR 6.4; $95 \% \mathrm{Cl}$ : 2.18-18.75; $p=0.001$ ).

The number of positive lymph nodes retrieved (PLNr)

TABLE 1 - Univariate analysis for number of lymph node retrieved

\begin{tabular}{|c|c|c|c|c|c|c|}
\hline \multirow{2}{*}{ Variable } & \multicolumn{2}{|c|}{ Lymph node retrieved } & \multirow{2}{*}{ OR } & \multicolumn{2}{|c|}{$\mathrm{Cl}(95 \%)$} & \multirow[b]{2}{*}{$p$} \\
\hline & $\leq 19(n=76)$ & $>19(n=73)$ & & Lower & Upper & \\
\hline Gender, n (\%) & & & & & & 0.807 \\
\hline Male & $57(50.4)$ & $56(49.6)$ & 1.00 & & & \\
\hline Female & $19(52.8)$ & $17(47.2)$ & 0.91 & 0.43 & 1.93 & \\
\hline Histology, n (\%) & & & & & & 0.856 \\
\hline SCC & $51(50.5)$ & $50(49.5)$ & 1.00 & & & \\
\hline Adenocarcinoma & $25(52.1)$ & $23(47.9)$ & 0.94 & 0.47 & 1.87 & \\
\hline Surgical access, n (\%) & & & & & & $<0.001$ \\
\hline Transhiatal & $27(84.4)$ & $5(15.6)$ & 1.00 & & & \\
\hline Thoracoscopy & $49(41.9)$ & $68(58.1)$ & 7.49 & 2.70 & 20.83 & \\
\hline cStage, n (\%) & & & & & & 0.174 \\
\hline I/II & $23(60.5)$ & $15(39.5)$ & 1.00 & & & \\
\hline III/IV & $53(47.7)$ & $58(52.3)$ & 1.68 & 0.79 & 3.55 & \\
\hline Grade of cellular differentiation, n (\%) & & & & & & 0.370 \\
\hline Well & $9(69.2)$ & $4(30.8)$ & 1.00 & & & \\
\hline Moderately & $47(48.5)$ & $50(51.5)$ & 2.39 & 0.69 & 8.30 & \\
\hline Poorly & $18(50)$ & $18(50)$ & 2.25 & 0.59 & 8.65 & \\
\hline $\mathrm{pCR}, \mathrm{n}(\%)$ & & & & & & 0.536 \\
\hline No & $42(48.8)$ & $44(51.2)$ & 1.00 & & & \\
\hline Yes & $34(54)$ & $29(46)$ & 0.81 & 0.41 & 1.56 & \\
\hline Age (years) & & & & & & $0.003^{* *}$ \\
\hline median (min; max) & $63(42 ; 79)$ & $60(37 ; 76)$ & 0.941 & 0.904 & 0.981 & \\
\hline Interval CRT-surgery (days) & & & & & & $0.169 * *$ \\
\hline median (min; max) & $96(38 ; 288)$ & $94(31 ; 293)$ & 0.995 & 0.987 & 1.002 & \\
\hline
\end{tabular}

Chi-squared test **Mann-Whitney 
was associated with gender $(p=0.044)$, adenocarcinoma histology $(p<0.001)$, and $p C R$ on the primary tumor site $(p<0.001)$ on univariate analysis (Table 3$)$. In the multiple regression analysis, $\mathrm{pCR}$ on the primary tumor (OR: $0.1 ; 95 \% \mathrm{Cl}$ : 0.04-0.25; $p<0.001$ ) and gender (male patients were more likely to have PLNr than women (OR 2.69; 95\%Cl: 1.03-7.04; $\mathrm{p}=0.044$ ) were independent variables associated with the number of PLNr. Surgical access was not related to PLNr.

Concerning lymphnodal recurrence, only $\mathrm{PCR}$ of the primary tumor was statistically significant (OR: $0.327 ; 95 \% \mathrm{Cl}$ : 0.08-0.99; $p=0.038$, Table 4). The surgical access was not related to lymphnodal recurrence.
TABLE 2 -There was no association of lymph node retrieved and pathological complete response (pCR)

\begin{tabular}{|c|c|c|c|c|c|}
\hline & & \multicolumn{2}{|c|}{ Lymph node retrieved } & \multirow[t]{2}{*}{ Total } & \multirow[t]{2}{*}{$p$} \\
\hline Thoracoscopy & & $\leq 19$ & $>19$ & & \\
\hline \multirow{2}{*}{ pCR (\%) } & No & $26(39.4)$ & $40(60.6)$ & 66 & \multirow[t]{3}{*}{0.535} \\
\hline & Yes & $23(45.1)$ & $28(54.9)$ & 51 & \\
\hline Total (\%) & & $49(41.9)$ & $68(58.1)$ & 117 & \\
\hline Transhiatal & & $\leq 19$ & $>19$ & & \\
\hline \multirow{2}{*}{ pCR (\%) } & No & $16(80)$ & $4(20)$ & 20 & \multirow[t]{2}{*}{0.626} \\
\hline & Yes & 11 (91.7) & $1(8.3)$ & 12 & \\
\hline Total (\%) & & $27(84.4)$ & $5(15.6)$ & 32 & \\
\hline
\end{tabular}

Fisher's exact test Fisher's exact test

TABLE 3 - Univariate analysis for metastatic lymph nodes

\begin{tabular}{|c|c|c|c|c|c|c|}
\hline \multirow{2}{*}{ Variable } & \multicolumn{2}{|c|}{ Metastatic lymph node (\%) } & \multirow{2}{*}{ OR } & \multicolumn{2}{|c|}{$\mathrm{Cl}(95 \%)$} & \multirow{2}{*}{$\mathrm{p}$} \\
\hline & No $(n=86)$ & Yes $(n=63)$ & & Lower & Upper & \\
\hline Gender, n (\%) & & & & & & 0.044 \\
\hline Male & $67(59.3)$ & $46(40.7)$ & 1.00 & & & \\
\hline Female & $28(77.8)$ & $8(22.2)$ & 0.42 & 0.17 & 0.99 & \\
\hline Histology, n (\%) & & & & & & $<0.001$ \\
\hline SCC & $74(73.3)$ & $27(26.7)$ & 1.00 & & & \\
\hline Adenocarcinoma & $21(43.8)$ & $27(56.3)$ & 3.52 & 1.71 & 7.24 & \\
\hline Surgical access, n (\%) & & & & & & 0.867 \\
\hline Transhiatal & $20(62.5)$ & $12(37.5)$ & 1.00 & & & \\
\hline Thoracoscopy & $75(64.1)$ & $42(35.9)$ & 0.93 & 0.42 & 2.10 & \\
\hline cStage, n (\%) & & & & & & 0.140 \\
\hline I/II & $28(73.7)$ & $10(26.3)$ & 1.00 & & & \\
\hline III/IV & $67(60.4)$ & $44(39.6)$ & 1.84 & 0.81 & 4.16 & \\
\hline Grade of cellular differentiation, $n$ (\%) & & & & & & $0.323 \#$ \\
\hline Well & $8(61.5)$ & $5(38.5)$ & 1.00 & & & \\
\hline Moderately & $65(67)$ & $32(33)$ & 0.79 & 0.24 & 2.60 & \\
\hline Poorly & $19(52.8)$ & $17(47.2)$ & 1.43 & 0.39 & 5.23 & \\
\hline $\mathrm{pCR}, \mathrm{n}(\%)$ & & & & & & $<0.001$ \\
\hline No & $39(45.3)$ & $47(54.7)$ & 1.00 & & & \\
\hline Yes & $56(88.9)$ & $7(11.1)$ & 0.10 & 0.04 & 0.25 & \\
\hline Age (years) & & & & & & $0.298^{\star *}$ \\
\hline median (min; max) & $63(41 ; 79)$ & $61(37 ; 78)$ & 0.979 & 0.941 & 1.018 & \\
\hline Interval CRT-surgery (days) & & & & & & $0.912^{\star *}$ \\
\hline median (min; max) & $94(36 ; 293)$ & $98(31 ; 244)$ & 0.999 & 0.991 & 1.006 & \\
\hline
\end{tabular}

Chi-squared test **Mann-Whitney test

TABLE 4 - Univariate analysis for lymph nodal recurrence

\begin{tabular}{|c|c|c|c|c|c|c|}
\hline \multirow{2}{*}{ Variable } & \multicolumn{2}{|c|}{ Lymph nodal recurrence } & \multirow{2}{*}{ HR } & \multicolumn{2}{|c|}{$\mathrm{Cl} 95 \%$} & \multirow[b]{2}{*}{$\mathrm{p}$} \\
\hline & No $(n=126)$ & Yes $(n=23)$ & & Lower & Upper & \\
\hline \multicolumn{7}{|l|}{ Gender, n (\%) } \\
\hline Male & $97(85.8)$ & $16(14.2)$ & 1,00 & & & \\
\hline Female & $29(80.6)$ & $7(19.4)$ & 1.32 & 0.554 & 3.15 & 0.53 \\
\hline \multicolumn{7}{|l|}{ Histology, n (\%) } \\
\hline Adenocarcinoma & $41(85.4)$ & $7(14.6)$ & 1,00 & & & \\
\hline SCC & $85(84.2)$ & $16(15.8)$ & 1.01 & 0.418 & 2.45 & 0.98 \\
\hline \multicolumn{7}{|l|}{ Surgical access, n (\%) } \\
\hline Transhiatal & $30(93.8)$ & $2(6.3)$ & 1,00 & & & \\
\hline Thoracoscopy & $96(82.1)$ & $21(17.9)$ & 2.91 & 0.681 & 12.4 & 0.15 \\
\hline \multicolumn{7}{|l|}{ cStage, n (\%) } \\
\hline I/II & $32(84.2)$ & $6(15.8)$ & 1,00 & & & \\
\hline III/IV & $94(84.7)$ & $17(15.3)$ & 0.981 & 0.389 & 2.47 & 0.97 \\
\hline $\mathrm{pCR}$ & $58(92)$ & $5(8)$ & 0.327 & 0.08 & 0.99 & 0.038 \\
\hline \multicolumn{7}{|c|}{ Grade of cellular differentiation, $\mathrm{n}(\%)$} \\
\hline I & $10(76.9)$ & $3(23.1)$ & 1,00 & & & \\
\hline II & $82(84.5)$ & $15(15.5)$ & 0.863 & 0.368 & 2.02 & 0.73 \\
\hline III & $31(86.1)$ & $5(13.9)$ & 0.945 & 0.351 & 2.54 & 0.91 \\
\hline Age (yr) & & & 0.965 & 0.921 & 1.01 & 0.13 \\
\hline Mean \pm SD & $61.4 \pm 8.6$ & $58.6 \pm 8.4$ & & & & \\
\hline Median (min; max) & $62.5(41 ; 79)$ & $60(37 ; 71)$ & & & & \\
\hline Interval CRT-Surgery (days) & & & 1,00 & 0.996 & 1.01 & 0.49 \\
\hline Mean \pm SD & $102.1 \pm 47.9$ & $111.1 \pm 36.5$ & & & & \\
\hline Median (min; max) & $94(31 ; 293)$ & $98(59 ; 177)$ & & & & \\
\hline
\end{tabular}

Chi-squared test 
This cohort comprising 149 patients submitted to neoadjuvant chemoradiotherapy using platinum- and taxanebased regimen followed by curative intent esophagectomy showed that thoracoscopy access was more likely to achieve lymph node retrieval than transhiatal access. On the other hand, surgical access did not differ in the number of positive lymph nodes retrieved, and also did not influence the risk for lymphnodal recurrence.

The transthoracic access provides a better pathological staging since it showed a higher number of LNr. However, the number of LNr is not the same for the good quality lymphadenectomy. In fact, with proper patient selection, transhiatal access with infracarinal lymphadenectomy may be enough to retrieve the nodal stations with a higher risk for positivity, avoiding lymphnodal recurrence. In this scenario, transhiatal approach turns to be a good option, since it is associated with reduced perioperative morbidity, a shorter hospital stay, and decreased in-hospital mortality rates $^{6,13}$, mainly in the cases of laparoscopic transhiatal esophagectomy ${ }^{3}$

Neither complete pathological response nor histological type was associated with the number of retrieved lymph nodes. Therefore, the number of LNr should be taken into consideration as one of the parameters when monitoring the quality of esophagectomy for cancer after neoadjuvant therapy, regardless of pathological response to neoadjuvant therapy or histological type. This finding differs from rectal cancer, in which pCR after chemoradiotherapy is associated with a lower number of lymph nodes harvested ${ }^{5}$. Squamous cell carcinoma showed a higher likelihood of a lower number of positive lymph nodes retrieved, but this is probably due to the higher response to neoadjuvant therapy.

Gender was associated with a higher likelihood of PLNr. While the mechanism underlying the association of lymph nodes metastasis and gender, epidemiological studies have reported a potential association between gender hormones and certain neoplasms, such as colorectal and thyroid cancers ${ }^{10,17}$

This study has several limitations. It was a retrospective, nonrandomized, single-institution; the number of patients, especially with adenocarcinoma, was relatively small; and different neoadjuvant chemotherapy other than platinumand taxane-based regimen, were not evaluated. Further studies with large controlled trials, comparing transhiatal and transthoracic access patients are required.

\section{CONCLUSION}

Thoracoscopic access is more accurate for pathological staging in patients submitted to esophagectomy after neoadjuvant chemoradiotherapy using platinum- and taxane-based regimen, even for a complete pathological response. With proper selection, transhiatal surgery may preserve the quality of lymph node excision of the positive lymph nodes.

\section{ORCID}

Flávio Roberto Takeda: 0000-0001-7338-922X

Francisco Tustumi: 0000-0001-6695-0496)

Bruna de Camargo Nigro: 0000-0003-2766-5013

Rubens Antonio Aissar Sallum: 0000-0003-1823-0042

Ulysses Ribeiro Junior: 0000-0003-1711-7347

Ivan Cecconello: 0000-0002-3535-4170
1. Almhanna K, Weber J, Shridhar R, Hoffe S, Strosberg J, Meredith K. Determining the optimal number of lymph nodes harvested during esophagectomy. J Gastrointest Oncol. 2016 Jun;7(3):387-94.

2. Andreollo, Nelson Adami et al. Pathologic Complete Response (YPTO YPN0) after chemotherapy and radiotherapy neoadjuvant followed by esophagectomy in the squamous cell carcinoma of the esophagus ABCD, arq. bras. cir. dig., 2018, vol.31, no.4. ISSN 0102-6720

3. Avital S, Zundel N, Szomstein S, Rosenthal R. Laparoscopic transhiatal esophagectomy foresophageal cancer.AmJSurg.2005Jul;190(1):69-74.

4. Bustamante-Lopez LA, Nahas CSR, Nahas SC, Marques CFS, Pinto RA Cotti GC, Imperiale AR, de Mello ES, Ribeiro U Junior, Cecconello I. Pathologic complete response implies a fewer number of lymph nodes in specimen of rectal cancer patients treated by neoadjuvant therapy and total mesorectal excision. Int J Surg. 2018 Aug;56:283-287.

5. ColvinH,DunningJ,KhanOA. Transthoracicversustranshiatalesophagectomy for distal esophageal cancer: which is superior? Interact Cardiovasc Thorac Surg. 2011 Feb;12(2):265-9.

6. Darling G. The role of lymphadenectomy in esophageal cancer. J Surg Oncol. 2009 Mar 15;99(4):189-93.

7. Hagens ERC, van Berge Henegouwen MI, Cuesta MA, Gisbertz SS. The extent of lymphadenectomy in esophageal resection for cancer should be standardized. J Thorac Dis. 2017 Jul;9(Suppl 8):S713-S723.

8. Ichimasa K, Kudo SE, Miyachi H, Kouyama Y, Ishida F, Baba T, Katagiri A, WakamuraK, HayashiT, Hisayuki T, KudoT, Misawa M, MoriY, Matsudaira S, Kimura Y, Kataoka Y. Patient gender as a factor associated with lymph node metastasis in T1 colorectal cancer: A systematic review and metaanalysis. Mol Clin Oncol. 2017 Apr;6(4):517-524.

9. Kang $\mathrm{CH}$, Kim YT, Jeon SH, Sung SW, Kim JH. Lymphadenectomy extent is closely related to long-term survival in esophageal cancer. Eur J Cardiothorac Surg. 2007 Feb;31(2):154-60.

10. Mota FC, Cecconello I, Takeda FR, Tustumi F, Sallum RAA, Bernardo WM. Neoadjuvant therapy or upfront surgery? A systematic review and meta-analysis of T2N0 esophageal cancer treatment options. Int J Surg. 2018 Jun;54(Pt A):176-181.

11. NapierKJ,ScheererM,MisraS.Esophagealcancer:AReviewofepidemiology, pathogenesis, staging workup and treatment modalities. World J Gastrointest Oncol. 2014 May 15;6(5):112-20.

12. RiceTW, PatilDT, BlackstoneEH.8theditionAJCC/UICC staging of cancers of the esophagus and esophagogastric junction: application to clinical practice. Ann Cardiothorac Surg. 2017 Mar;6(2):119-130.

13. Sun Y, Lv H, Zhang S, Bai Y, Shi B. Gender-Specific Risk of Central Compartment Lymph Node Metastasis in Papillary Thyroid Carcinoma. Int J Endocrinol. 2018 Mar 11;2018:6710326.

14. Takeuchi H, Kawakubo H, Takeda F, Omori T, Kitagawa Y. Sentinel node navigation surgery in early-stage esophageal cancer. Ann Thorac Cardiovasc Surg. 2012;18(4):306-13

15. Tanaka Y, Yoshida K, Suetsugu T, Imai T, Matsuhashi N, Yamaguchi K. Recent advancements in esophageal cancer treatment in Japan. Ann Gastroenterol Surg. 2018 May 28;2(4):253-265.

16. Toneto, Marcelo Garcia and VIOLA, Luciana Current Status of the multidisciplinary treatment of gastric adenocarcinoma. $A B C D$, arq. bras. cir. dig., 2018, vol.31, no.2. ISSN 0102-6720

17. van der Werf LR, Dikken JL, van Berge Henegouwen MI, Lemmens VEPP Nieuwenhuijzen GAP, Wijnhoven BPL; Dutch Upper GI Cancer Audit group. A Population-based Study on Lymph Node Retrieval in Patients with Esophageal Cancer: Results from the Dutch Upper Gastrointestinal Cancer Audit. Ann Surg Oncol. 2018 May;25(5):1211-1220.

18. Van Hagen P, Hulshof MC, van Lanschot JJ, Steyerberg EW, van Berge Henegouwen $\mathrm{Ml}$, et al. Preoperative chemoradiotherapy for esophageal or junctional cancer. N Engl J Med. 2012 May 31;366(22):2074-84.

19. Zhao Y, Zhong S, Li Z, Zhu X, Wu F, Li Y. Pathologic lymph node ratio is a predictor of esophageal carcinoma patient survival: a literature-based pooled analysis. Oncotarget. $2017 \mathrm{Jul}$ 15;8(37):62231-62239.

20. Fontan AJA, Batista-Neto J, Pontes ACP, Nepomuceno MDC, Muritiba TG, Furtado RDS. Minimally invasive laparoscopic esophagectomy vs. Transhiatalopenesophagectomyinachalasia:arandomizedstudy.ArqBras CirDig.2018Aug16;31(3):e1382.doi:10.1590/0102-672020180001e1382.

21. Lopes LP, Menezes TM, Toledo DO, DE-Oliveira ATT, Longatto-Filho A, Nascimento JEA. Early oral feeding post-upper gastrointestinal tract resection and primary anastomosis in oncology. Arq Bras Cir Dig. 2018 Jun 21;31(1):e1359. doi: 10.1590/0102-672020180001e1359.

22. Ivano FH, Mesquita LP, Simamura CM, Kuwaki GM, Colman JT, Campos GM. Pre and postoperative ph monitoring and weight loss analysis in patients undergoing gastric plication in association with fundoplication. Arq Bras Cir Dig. 2017 Oct-Dec;30(4):244-247. doi: 10.1590/01026720201700040004

23. Braghettol,CsendesA.Singleanastomosisgastricbypass(oneanastomosis gastric bypass or mini gastric bypass): the experience with billroth ii must be considered and is a challenge for the next years. Arq Bras Cir Dig. 2017 Oct-Dec;30(4):267-271. doi: 10.1590/0102-6720201700040010. 